\title{
Survey of Elementary School Teacher Needs on Video Learning Mathematics Based on Contextual Teaching and Learning in Palembang City
}

\author{
Ruri Tria Astika ${ }^{1}$, I Made Astra ${ }^{2}$, Makmuri $^{3}$, Sri Sumarni ${ }^{4}$, Windi Dwi Andika, \\ Endah Kinarya Palupi6 \\ ${ }^{1}$ Universitas Negeri Jakarta, Indonesia \\ ${ }^{2}$ Universitas Negeri Jakarta, Indonesia \\ ${ }^{3}$ Universitas Negeri Jakarta, Indonesia \\ ${ }^{4}$ Universitas Sriwijaya, Indonesia \\ ${ }^{5}$ Institut Pertanian Bogor, Indonesia \\ ${ }^{1}$ Correspondence Adress; ruritriaastika8@yahoo.com
}

\begin{abstract}
This study aims to gather information about the needs of elementary school teachers in the application of effective mathematics learning. This research is part of a research entitled Development of Learning Videos Based on Contextual Teaching and Learning Approaches to Improve Student Learning Outcomes of Primary Schools in Palembang City. The method used is research and development in the form of survey data. The survey method was carried out using a questionnaire in the Google form on 39 teachers in Palembang. The results of the distribution of the questionnaire interpreted that elementary school teachers were in dire need of media, especially in the form of contextual based mathematics learning videos. The conclusion of this research is the need for the development of learning videos to facilitate teachers in teaching contextual mathematics so that it will have a good impact on learning outcomes of elementary school students
\end{abstract}

Keywords: Survey of Elementary School Teacher Needs, Learning Videos, Contextual Teaching and Learning

\section{INTRODUCTION}

Mathematics is an important aspect in the world of education. The introduction of mathematics from an early age is the first step for students to enjoy the lesson by presenting material that is close to students' daily lives. But the reality is different, mathematics is considered difficult is one of the problems most often expressed by students in class. The issue that mathematics is difficult has received considerable critical attention (Maulidi, Apriliani, \& Syazali, 2019). This is seen as a major challenge faced by teachers to change students' mindset about mathematics.

These problems become homework that must be corrected by all parties both from government agencies, teachers, and parents. But in recent years, there has been an increase in interest in elementary school students in the field of mathematics. Recent evidence from the Program for International Study Assessment shows that mathematics competence has increased from 375 points in 2012 to 386 points in 2015 . The increase lifted Indonesia's position to 6th place compared to the second-lowest position in 2012 (OECD, 2016). Following the related article, Indonesia won eight gold medals in the 2016 International Mathematics and Science Olympiad (IMSO) for Primary School (IMSO, 2016). In the 2016 IMSO selection South Sumatra was not included in the 2016 IMSO selection list (IMSO \& OMSI, 2016). The results of these data indicate that mathematics interest is still ranked lowest. Seeing the gap, the 
researcher wants to conduct a survey of elementary school teachers related to mathematics learning to find out what factors influence the low mathematics achievement of students in elementary school.

The method used in research and development for this stage is the survey method. The most recent research results show that visual support on elementary school students' mathematics tests increases test scores and student test performance (Firat, 2017). Referring to the results of previous studies that with the support of technology can improve student mathematics test scores (Rahmawati, Lestari, \& Umam, 2019). However, research in the form of instructional media has not used a approach that is close to the daily lives of school students. So to continue the research the researcher will combine learning media with the Contextual Teaching and Learning approach to improve the learning outcomes of elementary school students.

\section{THE RESEARCH METHODS}

The research method used is research and development in the form of survey methods. Survey method is one of the methods that can be used in research development (Richey and Klein, 2007). This method uses sampling and the results are used to describe the entire population and use a set of questions that are generally in the form of questionnaires (Emzir 2013). This research was conducted at the State Elementary School in Palembang in January 2019. The data collection technique in this study was a questionnaire distributed to first grade teachers of the State Elementary School in Palembang City.

\section{THE RESULTS OF THE RESEARCH AND THE DISCUSSION}

Questionnaires were distributed to teachers in elementary schools using Google forms. The time given to complete the questionnaire for six days was 39 responses from elementary school teachers in Palembang. Based on the survey, it was found that elementary school teachers were in dire need of media in the form of learning videos based on Contextual Teaching and Learning in mathematics learning. The description can be seen in Figure 1- Figure 10.

In order for mathematics learning activities in elementary schools to be more interesting and interesting for students, what kind of learning media are really needed?

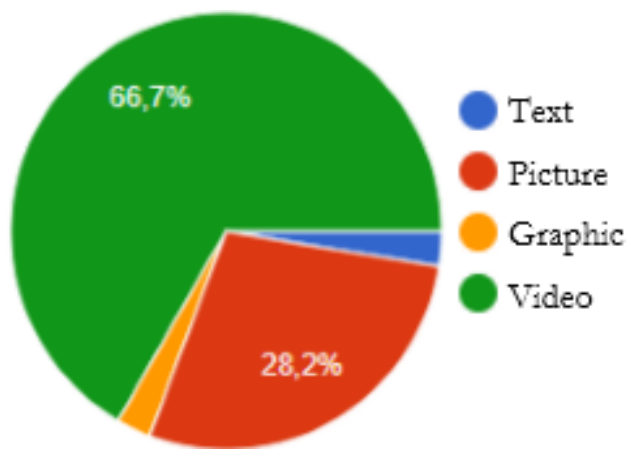

Figure 1. Interpretation of respondents' answers in response to the first question on the questionnaire 
What learning media are often used by teachers in the classroom learning process in mathematics?

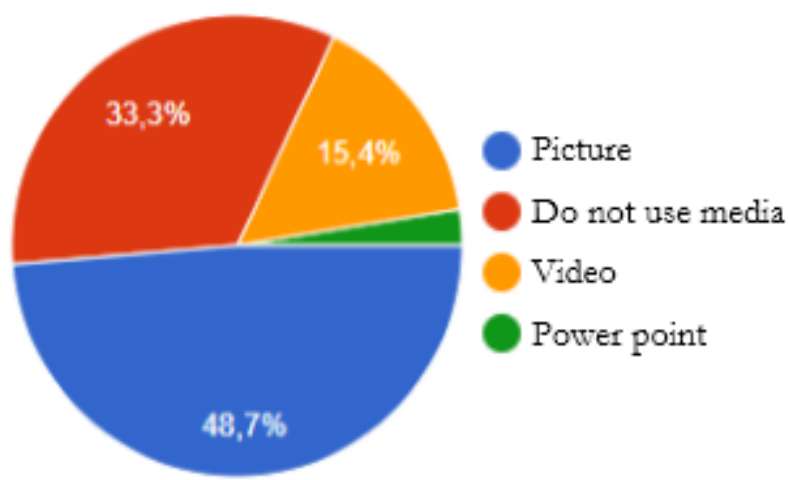

Figure2. Interpretation of respondents' answers in response to the second question on the questionnaire

In the process of learning mathematics in class, how often do you use learning media?

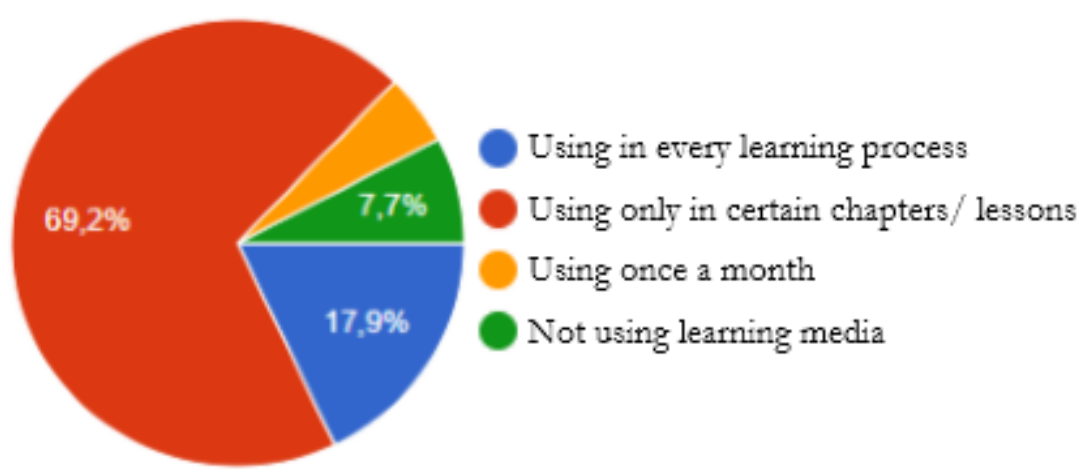

Figure3. Interpretation of respondents' answers in response to the third question on the questionnaire

The intensity of the use of instructional media, especially mathematics in the classroom is considered not optimal. Therefore, is it necessary to develop mathematics learning media in the form of videos?

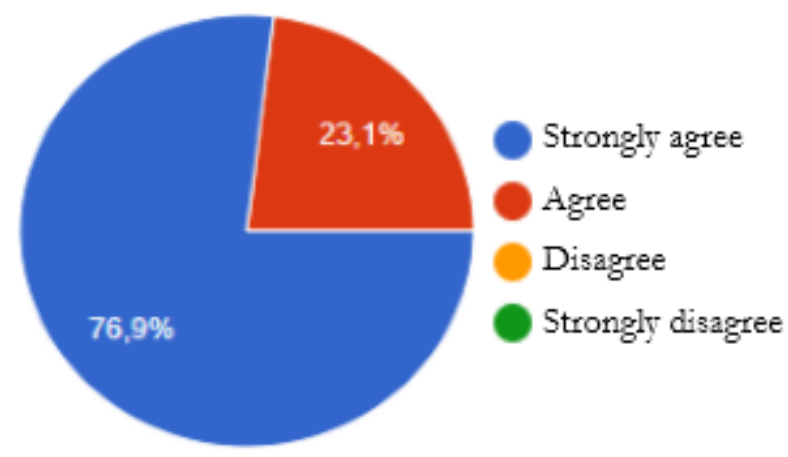

Figure 4. Interpretation of respondents' answers in response to the fourth question on the questionnaire 
Have you ever attended training on developing computer-based learning media for elementary schools?

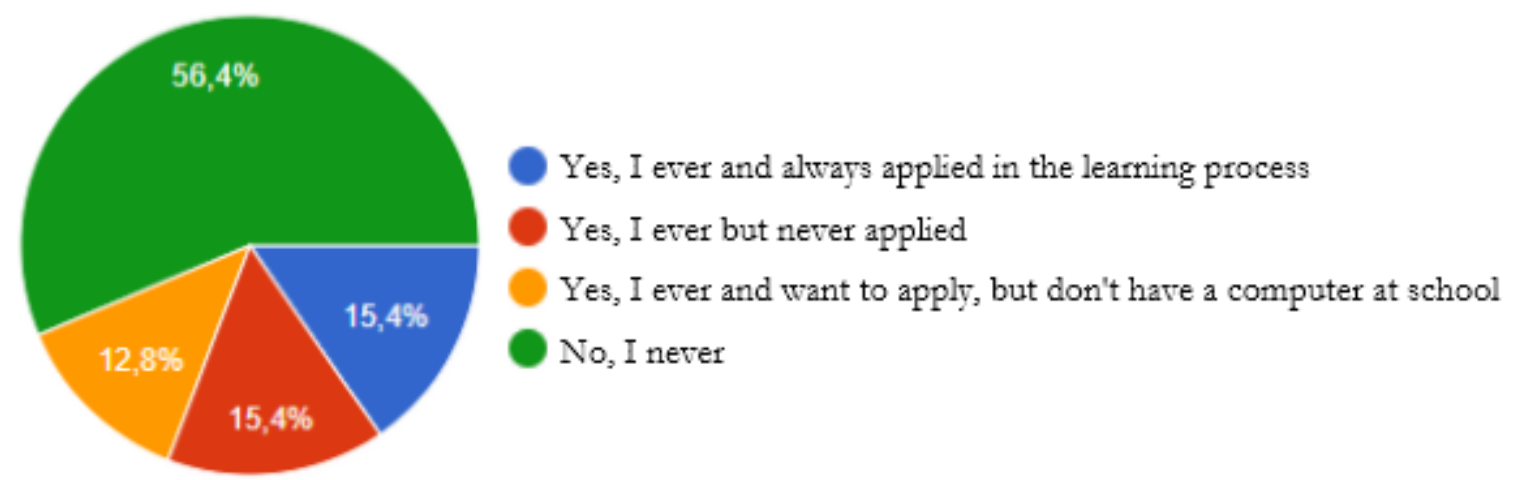

Figure 5. Interpretation of respondents' answers in response to the fifth question on the questionnaire

In explaining mathematical concepts, teachers should use innovative learning media (computerbased), what kind of media is suitable for elementary school children?

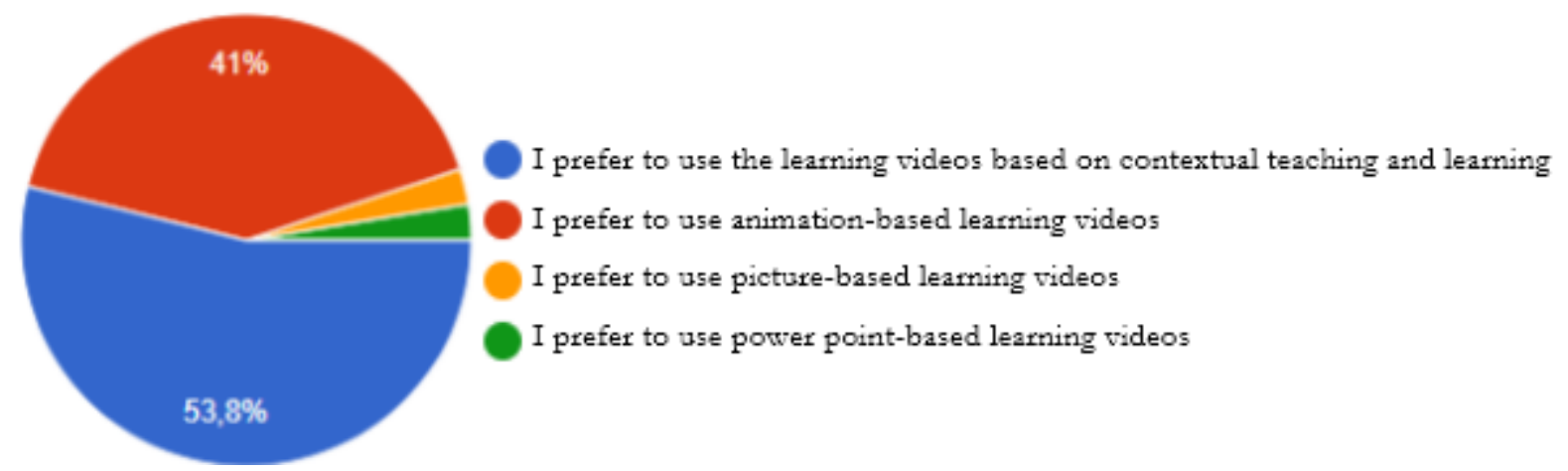

Figure 6. Interpretation of respondents' answers in response to the sixth question on the questionnaire

Do teachers need to provide learning media that students can use both in the classroom and at home?

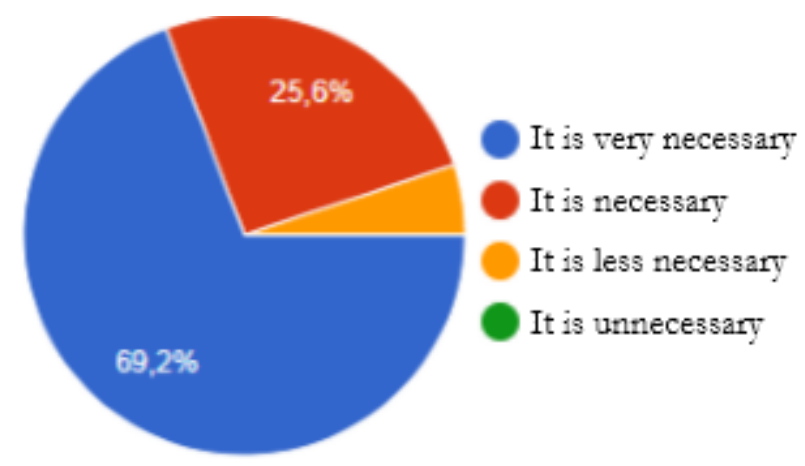

Figure 7. Interpretation of respondents' answers in response to the seventh question on the questionnaire 
Is it necessary to develop a video based on participatory learning and contextual learning that can make a major contribution in attracting students' interest in mathematics and improving their learning outcomes?

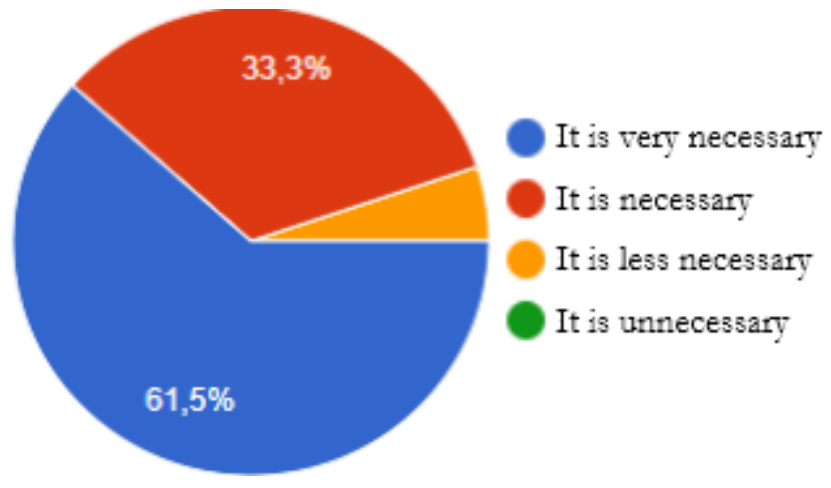

Figure 8. Interpretation of respondents' answers in response to the eleventh question on the questionnaire

If the school has complete computer facilities. Why not use it as a medium for learning mathematics in class?

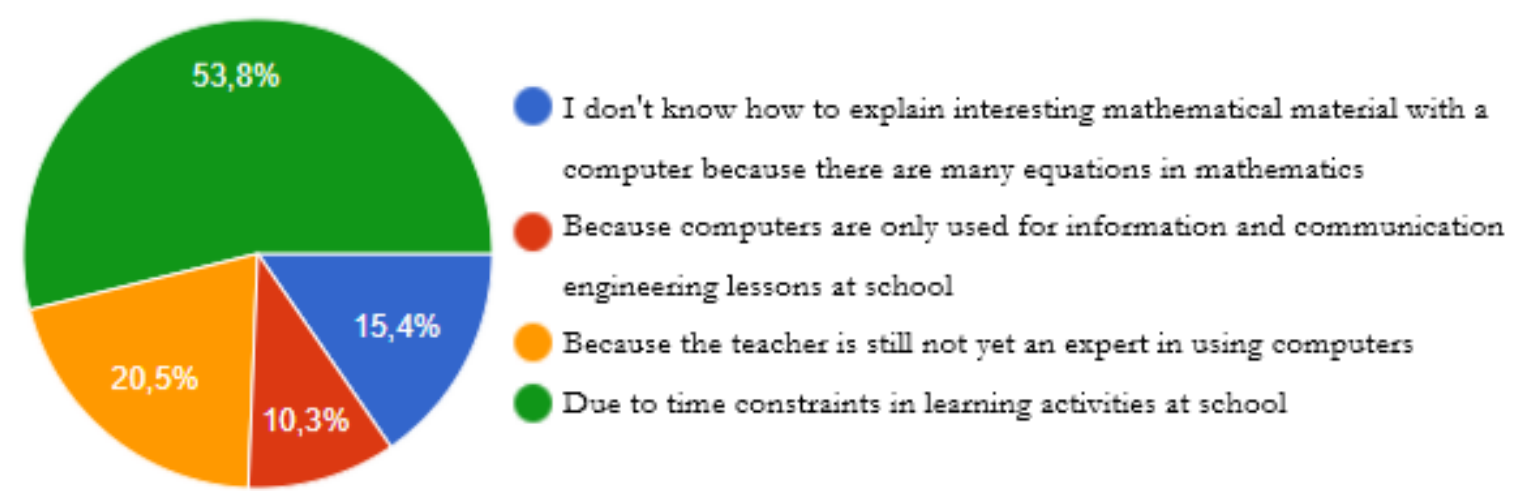

Figure 9. Interpretation of respondents' answers in response to the ninth question on the questionnaire

In the learning process in the classroom, what learning tools need to be developed in order to achieve learning objectives in mathematics?

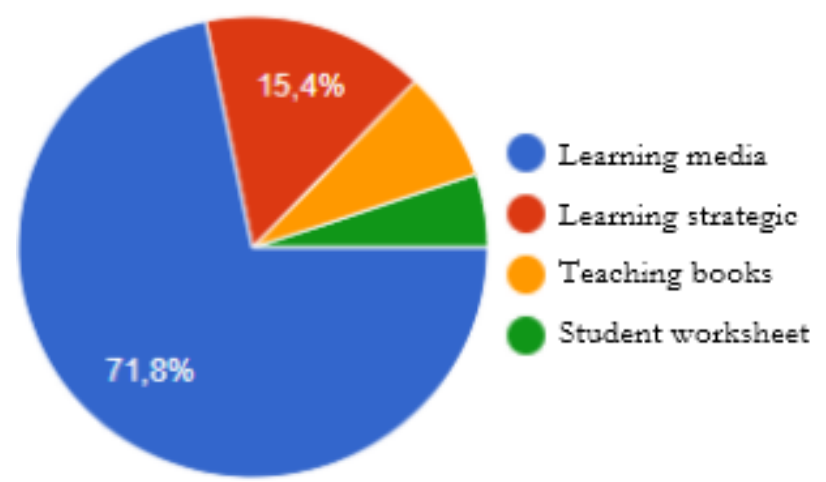

Figure 10. Interpretation of respondents' answers in response to the tenth question on the questionnaire 
Based on the questionnaire responses in this survey, it was found that the teacher needed a mathematics learning media in the form of video based on contextual teaching and learning in order to support student learning outcomes in elementary schools. Then, it is necessary to develop an attractive learning media to facilitate teachers achieving learning goals that have a good impact on primary school student learning outcomes. The existence of this learning video alleviates the teacher's task in explaining mathematics learning because the teacher acts as a facilitator in learning no longer being a teacher center but rather a student center. Students are directly involved in the activity by first looking at examples in the learning video that was developed. Learning videos can also be used in class or at home. So students can study at home because the final form of this product is a compact disk. Most important from the development of this product can teach teachers to be technology literate, at least the teacher is able to operate mathematics learning videos in the classroom.

In the era of rapid development of ICT (Information Communication and Technology), we make maneuvers in all aspects of life, one of which is in the field of education(Pereira, Romero, Pereira, \& Romero, 2017; Zezulka, Marcon, Vesely, \& Sajdl, 2016). Video becomes a medium where learners can critically analyze teaching practices in a way that is safe from their own teaching experience. In addition, the media gives more time for students to respond and reflect on what they read or observe, and also provides a more narrow view of class interactions, thus investigations focus more on children's thinking (Ball \& Cohen, 1999). For example, one can see a teaching video in class tracking the types of questions asked by the teacher and the types of thinking that arise from various questions (Roth McDuffie et al.,2014). The results of the study are intended to provide information for teachers about how the learning video template items can achieve the expected assessment results (Furió, Juan, Seguí, \& Vivó, 2015) an example of video based modeling (Groenendijk et al., 2013). Multimedia provides information to teachers on how a good learning video template is able to achieve learning objectives and assessment increases as expected. Further research results say that the teaching methods supported by simulations (computers) in teaching science are more effective than the classical teaching methods. This has proven to be an effective way to increase student success (Taşkin \& Kandemir, 2010). In line with the latest evidence that shows that the development of innovative and interactive technology applications have changed the method of learning (Luzón \& Letón, 2015)skills in the implementation of contextual learning/ contextual teaching and learning(Rokhman, Hum, \& Syaifudin, 2014).Mathematical learning encourages students to develop problem solving skills. Recent research results argue that students can grow in their abilities through some experience in developing contextual arguments (McFeetors \& Palfy, 2018).Several studies have shown students' instructions for learning in groups using an active learning approach, and improving the process or learning outcomes when compared to a more passive learning approach in completing tests(Benware \& Decia., 2014).Indeed, actively giving such instructional explanations to others during small group discussions (Van Blankenstein, Dolmans, Van der Vleuten, \& Schmidt, 2011) and during the test (Cohen, Kulik, \& Kulik, 1982) has been proven to help learning. 
Primary and secondary schools have significantly higher grades when the target subject is integrated with technology (Taylor, Casto, \& Walls, 2007). Similar research on the impact of technology in the classroom results confirms that technology has a media effect on the learning effectiveness of elementary school students (Chauhan, 2017). One of the integrated learning media technology is learning videos. There has been research on video information search in the last decade (Khan \& Alsalem, 2012). The findings show that students will refer to video instructions first before trying other forms of online instruction (May, 2010). The demonstration video provides a feasible way to support task completion. To further enhance learning, a better understanding of the student learning process is urgently needed (Meij, 2017). The study emphasizes that for instruction to succeed, various aspects of the environment must be considered such as the application of domain knowledge, conceptual theory, and evaluation of the overall quality of the designed environment(Sangsawang, 2015). Informing our understanding of the teacher's role in providing mathematics teaching that is interesting and beneficial for all students (Clarke \& Roche, 2017). Computer-supported methods in the form of videos have the potential to reduce teacher time and improve student performance, even for complex interpersonal problem solving skills (Campbell, Lison, Borsook, Hoover, \& Arnold, 1995). The learning video is segmented to strengthen the representation of procedures in memory for beginner learners thereby reducing cognitive load(Biard, Jamet, \& Jamet, 2017).Different research will be developed by researchers by looking at the needs of elementary school students where they are still learning at a concrete operational stage, for that the mathematics learning video developed will use a contextual teaching and learning approach so that learning outcomes can improve. Besides this video is a video simulation of mathematics learning by using a contextual teaching and learning approach to number material for first grade students of elementary school

\section{CONCLUSION AND SUGGESTION}

Based on the description above it can be concluded that elementary school teachers need video learning mathematics based on contextual teaching and learning. It is hoped that this can facilitate the teacher in explaining contextual mathematics material, so that students easily construct knowledge after seeing the learning video. Suggestions for teachers should always utilize the use of mathematics learning videos based on contextual teaching and learning, because learning can be more remembered when students are directly involved in class activities. For students, they should use video learning based on contextual teaching and learning as a reference when they want to learn both at school and at home. For further researchers, it is expected to gather other information related to the needs of elementary school teachers in learning mathematics in class.

\section{REFERENCES}

Ball, D., \& Cohen, D. (1999). Developing practice, developing practitioners. In L. DarlingHammond, \& G. Sykes (Eds.). Teaching as the learning profession (pp. 3-32). SanFrancisco, CA: Jossey-Bass Publishers. 


\section{$\underset{a}{a} \rho \mu$}

Biard, N., Jamet, E. and Jamet, E. (2017) 'Effects of segmentation and pacing on procedural learning by video’. https;//doi: 10.1016/j.chb.2017.12.002.

Benware, C. and and Decia., E. L. Ben (2014) 'Quality of Learning With an Active Versus Passive Motivational Set', 21(4), pp. 755-765.

Campbell, J. O., Lison, C. A., Borsook, T. K., Hoover, J. A. and Arnold, P. H. (1995) 'Using Computer and Video Technologies to Develop Interpersonal Skills', 11(2), pp. 223-239.

Chauhan, Sumedha, 'A Meta-Analysis of the Impact of Technology on Learning Effectiveness of Elementary Students', Computers and Education, 105(2017), 14-30 https://doi.org/10.1016/j.compedu.2016.11.005

Clarke, Doug, and Anne Roche, 'Using Contextualized Tasks to Engage Students in Meaningful and Worthwhile Mathematics Learning', Journal of Mathematical Behavior, 2017, 1-14 https://doi.org/10.1016/j.jmathb.2017.11.006

Cohen, P. A., Kulik, J. A., \& Kulik, C. C. (1982). Educational outcomes of tutoring: a metaanalysis of findings. American Educational Research Journal, 19,237e248. http://dx.doi.org/10.2307/1162567.

Emzir. (2013). Metodologi Penelitian Pendidikan: Kuantitatif dan Kualitatif. Jakarta: PT Raja Grafindo Persada.

Firat, Mehmet. "How real and model visuals affect the test performance of elementary students". Computers in Human Behavior.71, (2017), 258-265 <https://doi.org/10.1016/j.chb.2017.02.021>.

Furió, D., M. C. Juan, I. Seguí, and R. Vivó, 'Mobile Learning vs. Traditional Classroom Lessons: A Comparative Study', Journal of Computer Assisted Learning, 31 (2015), 189$201 \mathrm{https} / / /$ doi.org/10.1111/jcal.12071

Groenendijk, T., Janssen, T., Rijlaarsdam, G. and Bergh, H. Van Den (2013) 'Learning to be creative. The effects of observational learning on students' design products and processes', Learning and Instruction. Elsevier Ltd, 28, pp. 35-47. doi: 10.1016/j.learninstruc.2013.05.001.

Indonesia Rebut 8 Medali Emas di IMSO 2016, h. 1, 2016 (http://www.republika.co.id/berita/pendidikan/eduaction/16/11/12/ogjc5u257-indonesiarebut-8-medali-emas-di-imso-2016).

Khan, Emdad, and Adel Alsalem, 'Ivia : Interactive Video Intelligent Agent Framework for Instructional Video Information Retrieval', $64 \quad$ (2012), 18691https://doi.org/10.1016/j.sbspro.2012.11.022

Luzón, José María, and Emilio Letón, 'Use of Animated Text to Improve the Learning of Basic Mathematics', Computers and Education, 88 (2015), 119-28 https://doi.org/10.1016/j.compedu.2015.04.016 
Maulidi, I., Apriliani, V., \& Syazali, M. (2019). Fungsi Zeta Riemann Genap Menggunakan Bilangan Bernoulli. Desimal: Jurnal Matematika, 2(1), 43-47. https://doi.org/10.24042/djm.v2i1.3589

May, Yuen, 'Video Instructions as Support for beyond Classroom Learning', 9 (2010), 131318 https://doi.org/10.1016/j.sbspro.2010.12.326

McFeetors, P. Janelle, and Kylie Palfy, 'Educative Experiences in a Games Context: Supporting Emerging Reasoning in Elementary School Mathematics', The Journal of Mathematical Behavior, 2018, 1-23https://doi.org/10.1016/j.jmathb.2018.02.003

Van Der Meij, H. (2017). Reviews in instructional video. Computers \& education, 114, 164174.

Pengumuman Jadwal Pelaksanaan Tes Seleksi IMSO dan OMSI 2016, h.1 2016 (https://kpmseikhlasnya.com/berita-pengumuman-jadwal-pelaksanaan-tes-seleksi-imsodan-omsi-2016.html).

Pereira, A. C., Romero, F., Pereira, A. C., \& Romero, F. (2017). ScienceDirect ScienceDirect ScienceDirect ScienceDirect A review of the meanings and the implications of the Industry 4.0 review of the meanings and the implications of the Industry concept Costing models for capacity optimization in Industry 4 . 0: Trade-off between used capacity operational efficiency. Procedia Manufacturing, 13, 1206-1214.

Rahmawati, R., Lestari, F., \& Umam, R. (2019). Analysis of the Effectiveness of Learning in the Use of Learning Modules Against Student Learning Outcomes. Desimal: Jurnal Matematika, 2(3), 233-240.

Richey, Rita C. and James D. Klein. (2007). Design and Development Research: Methods, Strategies, and Issues. New Jersey: Lawrence Erlbaum Associates.

Rokhman, F., Hum, M., \& Syaifudin, A. (2014). Character Education For Golden Generation 2045 ( National Character Building for Indonesian Golden Years ). Procedia - Social and Behavioral Sciences, 141, 1161-1165. https://doi.org/10.1016/j.sbspro.2014.05.197

Roth McDuffie, A., Foote, M. Q., Bolson, C., Turner, E. E., Aguirre, J. M., Bartell, T. G., et al. (2014). Using video analysis to support prospective K-8 teachers' noticing of of students' multiple mathematical knowledge bases. Journal of Mathematics Teacher Education, 17(3), 245-270

Sangsawang, T. (2015). Instructional design framework for educational media. Procedia-Social and Behavioral Sciences, 176, 65-80.

Taşkm, N., \& Kandemir, B. (2010). The affect of computer supported simulation applications on the academic achievements and attainments of the seventh grade students on teaching of science. Procedia-Social and Behavioral Sciences, 9, 1379-1384.

Taylor, L. M., Casto, D. J., \& Walls, R. T. (2007). Learning with versus without technology in elementary and secondary school. Computers in human behavior, 23(1), 798-811. 


\section{$\mathbf{a} \delta \rho \mu$ \\ allobar : Jurnal Pondidilkan Matomatika
P-ISSN $2086-5872$
e-ISSN $2540-7562$}

Al-Jabar: Jurnal Pendidikan Matematika

Vol. 10, No. 2, 2019, Hal 251 - 260

Van Blankenstein, F. M., Dolmans, D. H. J. M., Van der Vleuten, C. P. M., \& Schmidt, H. G. (2011). Which cognitive processes support learning during small-group discussion? The role of providing explanations and listening to others. Instructional Science, 39, 189e204. http://dx.doi.org/10.1007/s11251- 009-9124-7. 